\title{
Andries van Aarde se vaderlose Jesus
}

\author{
Jurie H le Roux \\ Departement Ou-Testamentiese Wetenskap \\ Universiteit van Pretoria
}

\begin{abstract}
Andries van Aarde's fatherless Jesus

This article focuses on Andries Van Aarde's book, "Fatherless in Galilee", is an important contribution to the historical Jesus study in South Africa. Van Aarde depicted Jesus as someone who grew up fatherless. For Jesus this meant a lifelong struggle against slander and the exclusion from the temple and the presence of God. Jesus nevertheless trusted God who filled Jesus' emptiness. Jesus was baptized and then started a ministry, focusing on the outcasts of society. He preached that the kingdom of God has come and that the people of this kingdom can experience God, as well as forgiveness of sins. Jesus died but arose in the kerygma. The article also refers to the struggle of the authors of the New Testament writings to understand and express the Jesus event.
\end{abstract}

\section{INLEIDING}

In sy groot navorsingsoorsig oor die historiese-Jesus-ondersoek vertel Albert Schweitzer waarom hierdie soort ondersoek besondere hoogtes in Duitsland kon bereik het. Daar was veral vier voorwaardes: filosofiese onderlegdheid, kritiese ingesteldheid, 'n historiese bewussyn en 'n religieuse gevoel. Binne die Duitse gees het hierdie vier faktore tot 'n harmoniese eenheid gegroei wat die historiese Jesusondersoek op 'n baie beslissende manier gerig het. Op so 'n manier dat "the greatest achievement of German theology is the critical investigation of the life of Jesus" (Schweitzer 1936:1). So iets was in Suid-Afrika nie moontlik nie. Die vier voorwaardes het nie net in die geheel of gedeeltelik ontbreek nie, maar die teologiese klimaat was ook nie vir so iets bevorderlik nie (vgl Le Roux 1993:107-114). Andries van Aarde se Fatherless in Galilea is waarskynlik die eerste werklike "vollengte" kritiese geskiedenis van Jesus waarin die ganse lewensloop van Jesus ondersoek en deur 'n Suid-Afrikaner (meer bepaald: Afrikaanssprekende) vertel is. Die boek was alreeds in 1998 voltooi, maar het eers in 2001 verskyn. In hierdie artikel word Van 
Aarde se Jesusboek bespreek. Veral die buitelyne van die historiese Jesus se lewensloop. Eers volg daar egter 'n paar algemene opmerkings.

\section{SO 'N WERK IS NOODSAAKLIK}

Vroeër was dit makliker. Baie makliker. Die verkondigde Christus was die belangrikste en kennis van die historiese Jesus van geen wesentlike betekenis. By Nicea en Chalcedon is die finale slag gelewer en dit was nie meer nodig om agter hierdie belangrike belydenisse terug te val nie. Dalk kon dit nou nog gewerk het, maar toe het daar iets ingrypend gebeur: die opkoms van die historiese verstaan van die wêreld, mense en tekste in die negentiende eeu. Dit was die eeu van die geskiedenis: "Das 19. Jh. ist in einem prägnanten Sinne das Jahrhundert der Geschichte und der Geschichtsschreibung gewesen" (Mehlhausen 1984:643). Geskiedenis en geskiedskrywing het 'n manier geword waarop by mense hulleself kon begryp: "So entsteht das Grundschema des modernen historischen Denkens: die Vorstellung, Geschichte sei der Weg - oder Umweg der Menschheit zu sich selbst” (Mehlhausen 1984:643). Deur die geskiedenis wou mense insig in hulleself asook menswees verkry. Dinge (objekte) word eers begryp wanneer dit histories verstaan word. Historiese verstaan het 'n lewenstyl geword, 'n manier om ons menswêreld te verstaan, 'n manier om die alledaagse lewe te begryp en probleme op te los. Hierdie historiese impak sou die historiese-Jesus-ondersoek ingrypend beïnvloed (Borg 1991:8-14). In die lig hiervan is Van Aarde se Jesusboek vir die Suid-Afrikaanse akademiese en geloofsgemeenskap nogal baie belangrik. Veral sy waagmoed, sy eerlik-heid en sy beklemtoning van die "geloofswaarde" van 'n historiese ondersoek (Van Aarde 2001:204).

Van Aarde se geskiedenis getuig van historiese waagmoed. Vir die vroeë kerk was dit nie so belangrik om Christus na die vlees te ken nie. Wat van die historiese Jesus oorgebly het, was 'n vae herinnering. Enkele losstaande woorde en die herinnering aan wonderwerke, sy dood en sy opstanding. Van 'n biografie oor die historiese Jesus was daar geen sprake nie. By Chalcedon het dinge vererger: “... its doctrine of the two natures dissolved the unity of the Person, and thereby cut off the last possibility of a return to the historical Jesus" (Schweitzer 1936:3). In die Christologiese besinning na Chalcedon het die menslike natuur al hoe meer aan die goddelike ondergeskik geraak; Jesus het meer goddelik as menslik begin word; meer die Seun van God wat uit die hemel neergedaal het as die mens wat in Nasaret gewoon het. Kortom: "In deze goddelijke glans verbleekte zijn menszijn” (Den Heyer 
1996:23-24). Historiese Jesusnavorsing het byna onnodig geword. Van Aarde se werk is dus daarin belangrik dat dit Suid-Afrikaners vertel hoe om agter Chalcedon, Nicea, die Nuwe Testament en ander nie-kanoniese geskrifte 'n greep op die vergange Jesuswerklikheid te kry.

'n Belangrike kenmerk van Van Aarde se ondersoek is sy historiese eerlikheid. Sy boek is nie net 'n eerlike soeke na die historiese Jesus nie, maar ook 'n eerlike poging om met die geskiedenis se skerpkante om te gaan. En vir elke teologie lê die tongtippie-toets in sy eerlikheid oor die verlede. Veral oor die historiese Jesus: "The critical study of Jesus has been for theology a school of honesty" (Schweitzer 1936:5). Om eerlik te wees, is egter nie so maklik nie. Dit kan selfs traumaties wees want geskiedenis vernietig die gangbare en populêre siening van sake. Dit lê nogal in die aard van geskiedenis. Dit is soos 'n ysterbal: dit vernietig, keerom, herskep en herskryf. 'n Historikus is soms soos 'n smid. Met sware harde slae word hy die algemeen-aanvaarbare, maar onhistoriese sieninge oor die verlede (of die historiese Jesus) uitmekaar (Troeltsch 1913:716; 1922:730; Klapwijk 1970:89-96). Geskiedskrywing (veral oor die historiese Jesus) was (en is nog steeds) 'n gevaarlike onderneming. 'n Goeie voorbeeld hiervan is David Friedrich Strauss: "His 'Life of Jesus' was his ruin" (Schweitzer 1936:5). Vyf en twintig jaar na die verskyning van sy Jesusboek het Strauss die gevolge daarvan beskryf: hy moes sy universiteitspos neerlê, het vriende verloor en het 'n eensame man geword (Schweitzer 1936:97-120). Eerlikheid in verband met Jesus het dus 'n prys. En dit is die belangrike van Van Aarde se boek dat hy ons deur hierdie historiese smeltkroes (wat dreig om alles te vernietig) neem sodat die betekenis van Jesus opnuut kon blyk. Sy boek vernietig inderdaad bestaande sieninge, maar dit help ons ook om ander nuwe perspek-tiewe op Jesus raak te sien.

Van Aarde beklemtoon dat geloof en historiese inligting mekaar nie uitsluit nie. Volgens sommige is kennis van die historiese Jesus sinloos. Geloof berus immers nie op historiese feite en rekonstruksies nie. Vir diesulkes is historiese kennis dikwels van minder belang. Dit is bloot insidenteel, toevallig en kan geen finale waarhede waarborg nie. Kennis van die historiese Jesus is dus van terloopse en ondergeskikte belang (vgl Du Toit 1985:257-279). Sodoende kom ons nie verder as Lessing en die agtiende eeu se byna veragting vir die geskiedenis nie. Tussen die historiese Jesus en die kerk se Christus was 'n aaklige onoorbrugbare kloof. Niemand kon daaroor nie. Lessing het gesê hy sou nie eers waag om te spring nie want sy bene was te swak (Thiselton 1980:53-63). Danksy die opkoms van die historiese bewussyn 
in die negentiende eeu het die siening in verband met geskiedenis radikaal verander. Nou is beweer dat alles in en deur die geskiedenis gevorm is (vgl Von Harnack 1908:177-179; 1990:133-138; Gunkel 1926/1927:533; Borg 1987:1-17). Vir Van Aarde het die geskiedenis ook groot betekenis: “... the Jesus of history is not irrelevant" (Van Aarde 2001:20). God se heil het in die geskiedenis gestalte gekry; God het God self in hierdie mens, hierdie Jesus bekendgemaak; God het in ons menswêreld en op 'n menslike manier deur die mens Jesus gestalte gekry. En die spore daarvan vind ons in die Nuwe Testament en ander antieke literatuur. Geloof roep dus om kennis van die historiese Jesus. Hiersonder word die heil virtueel, word Jesus bloot ' $n$ fantoom en alle spreke oor Christus blote vlietende gedagtes wat nêrens in ons menslike bestaan gegrond is nie (Van Aarde 2001:18). Of soos Van Aarde dit saamvat: "If (historical) inquiry is denied at the doorstep, doubt will come through the window" (Van Aarde 2001:23).

\section{DIT MOET EG HISTORIES WEES}

Van Aarde se boek is 'n belangrike gebeurtenis in die Suid-Afrikaanse Bybelwetenskap. Dat sulke histories-kritiese werke oor Jesus nie eintlik in SuidAfrika verskyn nie, is onder andere 'n bewys daarvan dat ons wye en droewe land bogenoemde vier voor-waardes gemis het. Veral die historiese verstaan van tekste (vgl Le Roux 1993:16-87). En wie histories werk, moet blyke van sy of haar historiese vaardighede gee. Dit beteken dat 'n mens voortdurend aan jou historiese lense moet slyp sodat dit telkens nuut en anders na die verlede (of die historiese Jesus) kan kyk. Hoe die historiese proses presies moet verloop, is nie seker nie. Elkeen gee sy of haar eie inhoud daaraan. Of soos Albert Schweitzer gesê het: "The historical study of the life of Jesus has had to create its own methods for itself" (Schweitzer 1936:6). By Van Aarde het dit op 'n bepaalde manier beslag gekry. Ons let kortliks op die volgende:

Wie historiese werk, moet na die stemme van gister en eergister luister (vgl Schnelle 1999:18-26, 177-214). Anders gestel: moet die geskiedenis van die navorsing oor die historiese Jesus ernstig neem. Niemand kan vandag sinvol oor die historiese Jesus praat sonder kennis van die grootgesprek hieroor in die negentiende asook die twintigste eeu nie. Hierdie gesprek vorm die historiese verstaanshorison waarbinne 'n mens oor Jesus moet praat. Dit is egter een van die sterkpunte van Van Aarde dat hy met die verlede in gesprek bly. Hy het die twee-eeu-lange kritiese gesprek oor Jesus verinnerlik en daarom is sy werk ook op die een of ander manier 'n 
kritiese reaksie daarop. Verskillende mense het hom beïnvloed. William Wrede het hom geleer dat die evangelies Jesus reeds geïnterpreteer het; dat die Markusevangelie 'n teologiese werk met ' $n$ apokaliptiese interpretasie van Jesus is; dat agter die oudste evangelie, Markus, 'n reeds geïnterpreteerde Jesus is; dat die greep op 'n historiese Jesus byna onmoontlik is (Van Aarde 2001:32; vgl Schweitzer 1936:328-338). Van Aarde begin sy werk met 'n verwysing na die slot van Albert Schweitzer se boek oor die Jesusnavorsing: elkeen sal in sy of haar daaglikse lewenstryd leer wie Jesus vir hom of haar is; (Van Aarde 2001:1-4; Schweitzer 1936:401); in die laaste hoofstuk van sy boek gee Van Aarde besondere betekenis hieraan (Van Aarde 2001:195-204). Van Aarde se kritiese omgang met Bultmann is ook duidelik: dinge soos die mitologiese wêreldbeeld van die Nuwe-Testamentiese skrywers, die onderskeiding Geschichte en Historie, die aard van die historiese Jesus se werk, die historiese basis van Jesus se doop, ensovoorts illustreer sy worsteling met Bultmann (Van Aarde 2001:15, 22-23, 54-57, 60). 'n Baie belangrike (en dalk ook unieke) kenmerk van Van Aarde se historiese-Jesus-navorsing is sy betrokken-heid by sowel die Context Group as die Jesus Seminar: hy het dus 'n hele aantal jare saam met die denke en metodes van die voorste navorsers oor die historiese Jesus gegroei en dit het sy verstaan van die historiese Jesus gevorm. Om 'n laaste naam te noem: John Dominic Crossan. Op verskeie maniere blyk Van Aarde se respek vir hom as een van vandag se voorste historiese-Jesus-navorsers (Van Aarde 2001:30-32, 62-63, 65-71, 168-169, 188-190). Kortom: die historiese-Jesus-navorsing kom 'n lang pad en wie nie hiervan kennis neem nie, mis 'n belangrike verstaanshorison (vg1 Le Roux 1997:401-423).

Een van die eerste stappe in enige historiese ondersoek is die kritiese ontleding van bronne. Dat Jesus God is, dat hy tegelyk God en mens is - soos die vierde-eeuse belydenisskrifte dit verwoord - is latere interpretasies en kan nie as primêre bronne vir die Jesustyd aanvaar word nie (vgl Pelican 1971:173-210). Na die vroegste bronne moet eerder deurgedring word. Die probleem is egter dat bronne skaars en historiese inligting min is (Van Aarde 2001:58). Dit beteken egter nie dat 'n mens moet waag nie (Van Aarde 2001:55). Elke bron wat lig op die historiese Jesus kon werp, het Van Aarde met die grootste sorg bekyk. In elke brokstukkie wou hy die naklanke van 'n Jesusverlede hoor en daarom het hy goed probeer luister. Selfs mites en mitologiese taal was vir hom belangrik: “... myths represent an interpreted reflection on the identity of Jesus, just as any other attestation to his words and deeds does" (Van Aarde 2001:27; vgl 28-30, 48-50). Nadat Van Aarde sy bronne deeglik getoets en hiërargies vanaf die oudste tot die jongste georden het, kon hy na die 
vroegste getuienis terugwerk. So iets was uiteraard nie maklik nie. Om Van Aarde te verstaan, moet 'n mens dan ook voortdurend sy bronne-daterings in gedagte hou. Volgens hom is kennis oor Jesus aanvanklik monde-lings oorgelewer en eers vyf en twintig jaar na sy dood vir die eerste keer deur iemand (Paulus) wat Jesus nooit persoonlik geken het nie, neergepen. Min of meer dieselfe tyd toe Paulus sy eerste briewe in die vyftigerjare $\mathrm{nC}$ begin skryf het, het 'n spreuke-evangelie tot stand gekom waarna geleerdes as Q verwys. Twee resensies van die kern (die "formatiewe stratum") van hierdie evangelie het daarna die lig gesien. Die finale redaksionele stratum weerspieël net soos die kanonieke evangelies die worsteling van die Palestynse dorpie-gemeenskappe in noord-Galilea en suid-Sirië gedurende die periode toe Israeliete die verlies van hulle sentrale kulturele simbool, die tempel in Jerusalem, moes verwerk. Volgens Van Aarde (1999:804) is daar raakpunte tussen sekere uitsprake van Jesus wat Markus berig en die twee resensie van die Spreuke-evangelie Q. Lukas en Matteus het 'n groot aantal van Jesusuitsprake vanuit die derde resensie van Q oorgeneem en verwerk (Van Aarde 2001:109).

Die evangelie van Markus het in ongeveer $70 \mathrm{nC}$ verskyn. Benewens die Spreuke-evangelie Q het Markus in $85 \mathrm{nC}$ as bron vir die evangelie van Lukas gedien en in 85-90 nC vir Matteus. Johannes se evangelie het onafhanklik van Markus, Lukas en Matteus aan die einde van die eerste eeu tot stand gekom. Gedurende die tweede eeu het daar ook Gnostiese werke verskyn wat vir die Jesusstudie belangrik is (Van Aarde 2001:10; vgl Le Roux 1996:653-670). Enkele van die Jesusuitsprake in die Evangelie van Tomas bestaan onafhanklik van die kanonieke evangelies en is moontlik voor Markus neergeskryf.

Nog 'n belangrike kenmerk van Van Aarde se historiese ondersoek is die invloed van sosio-historiese insigte. Geen geskiedenis kan meer die impak hiervan ontglip nie. Histories-kritiese metodes op sigself is nie meer voldoende nie. Dit moet deur die sosiale wetenskappe aangevul word (Van Aarde 2001:36). In ons tyd het die Bybelwetenskap multidissiplinêr en interdissiplinêr geword (Van Aarde 2001:31). Van Aarde verklaar dan ook: "The historical investigation practiced in this book is multidisciplinary in nature" (Van Aarde 2001:14). 'n Mens sien dit veral in die sosiologiese en narra-tologiese lees van tekste. Vir Van Aarde is die sosiaalwetenskaplike verstaan van die Nuwe Testament geweldig belangrik. Alhoewel Bruce Malina en Paul Hollenbach hom aanvanklik gehelp het, het hy sy eie sosiaalkritiese denke ontwikkel. Hierdie perspek-tiewe het hom gehelp om die historiese Jesus beter te verstaan: "Several aspects of my portrayal of the historical Jesus have 
become to me more and more intelligible as my application of social-scientific criticism has increased over the years" (Van Aarde 2001:42). Op een punt het dit hom beslissend beïnvloed: die beginpunt van sy historiese Jesus. Van Aarde begin nie sy verhaal by Jesus se dertigjarige ouderdom en sy doop nie, maar by sy geboorte (Van Aarde 2001:72-81). Meer bepaald: die onvolledige familie waarin Jesus gebore en groot geword het. Hiertoe het Van Aarde se sosiale kritiek hom gelei. Volgens hom bestaan alle gemeenskappe uit bepaalde sosiale instellings soos die familie, die ekonomie, die politiek en die godsdiens. In die Mediterreense wêreld gedurende die eerste eeu het die familie sentraal gestaan. Wat daar gebeur het, het 'n mens se lewe bepaal. Buite die familiestrukture en -bande was die lewe hel (Van Aarde 2001:45). En dit was waarom Van Aarde besluit het om by Jesus se geboorte en familiekonteks te begin (Van Aarde 2001:75).

Een saak moet baie duidelik gestel word: Van Aarde probeer geensins om 'n presiese beeld van die historiese Jesus te skets nie. Soos alle historiese gebeurtenisse lê die historiese Jesus buite enige historiese greep (vgl hieronder). Niemand kan hom presies beskryf nie. En dit weet Van Aarde ook. Gevolglik het hy 'n Weberiaanse ideëeltipe van die historiese Jesus gemaak. So 'n ideëeltipe is bloot 'n teoretiese konstruksie waarin 'n aantal moontlike historiese gebeure en insigte tot 'n koherente eenheid saamgebind word. So 'n konstruksie vorm dan die betekenishorison van waaruit die verlede verstaan en beskryf word. Een ding is egter belangrik: dit kan geensins die geskiedenis presies beskryf nie; dit kan hoogstens historiese moontlikhede beklemtoon; dit kan hoogstens vertel hoe historiese gebeurtenisse kon plaasgevind en mense kon reageer het (Weber 1949:90-96). Kortom: 'n ideëeltipe is 'n teoretiese konstruksie wat nie noodwendig met die empiriese werklikheid ooreenstem nie (Van Aarde 2001:40). Van Aarde se ideeltipiese Jesus stem waarskynlik nie presies met die historiese Jesus ooreen nie, maar dit belig op 'n treffende manier wat die ervaringe van 'n vaderlose seun in die Mediterreense wêreld gedurende die eerste eeu kon gewees het (vgl Craffert 1999b:1-21).

\section{JESUS SE WÊRELD}

Soms het Van Aarde te min van Jesus vertel. Dikwels het hy so by die debat betrokke geraak dat te min van die Jesusverhaal navore gekom het. Gevolglik lê Van Aarde se Jesusbeeld in sy talle polemiese diskussies en gesprekke met ander Jesusnavorsers ingebed. Hieronder volg enkele baie breë pennestrepe om hierdie Jesusbeeld 'n bietjie duideliker te profileer. Wie hierdie Jesusbeeld "aanskou", word deur die 
ontsaglike menslikheid daarvan aangegryp. Jesus was 'n "nobody". So is hy gebore, so het hy geleef en so het hy gesterf: "Jesus of Nazareth died as he was born: a nobody among nobodies" (Van Aarde 2001:43). Hierdie "nobodies" (die uitgeworpenes, die kinders, die vrouens) het egter sy liefde en medemenslikheid so intens ervaar dat hy in die herinnering bly voortleef het. Ons begin die verhaal by sy geboorte en die land van sy geboorte.

Jesus is in Galilea gebore (vgl Van Aarde 2001:72, 83-85). Die Galilese wêreld waarin hy sy verskyning gemaak het, was veeltalig en deur heidene en Israeliete bewoon. Gemengde huwelike was volop en die Galilese Jode is soms vanweë hulle gemengde herkoms, "Samaritane", genoem. Langs die Galilese meer en ook 'n paar myl daar-vandaan was dorpe en stede. In die stede was daar dikwels tempels gewy aan die keiser en allerlei gode, 'n koninklike paleis, militêre fortifikasies en woonruimtes met mosaïek-vloere waar die aristokrate feesgevier het. Langs die meer het daar ook boere gewoon. Elke dag het hulle vanuit ou verslete bote hulle daaglikse brood verdien. Ander boere het weer op flentertjies landbougrond geboer en as armoede en skuld hulle gedruk het, het hulle ander ambagte beoefen. Een moontlikheid was om skrynwerker te word (Van Aarde 2001:75; vgl Botha 2000:1-18).

Dan was daar ook nog die magspel van die tempelamptenare. In Jerusalem is 'n eng religieuse beleid geformuleer wat die hele gemeenskap radikaal beïnvloed het. Niemand kon die mag van hierdie tempelstaat ontkom nie. Alles het om reinheid en onreinheid gewentel en die hele gemeenskap is deur wette en eindelose stipulasies gereguleer en beheer. Dit was 'n eksklusivistiese samelewing wat hiërargies georden was en waarin elkeen se plek duidelik uitgespel is. Dan was daar ook nog die amptenare wat die tempelbelasting geïn het. Hulle het ook gekyk of die wette toegepas word en of die gemeenskap "rein" leef (Van Aarde 2001:74-75). Vir gewone boere was die druk soms te veel. Die dubbele belasting aan die Jerusalemse tempel en die Herodiaanse koningshuis het hulle van hulle grond gedryf en die familie laat verbrokkel (Van Aarde 2001:128).

In elke Joodse samelewing in Galilea het die familie sentraal gestaan. Dit was 'n mannewêreld en alle mag was in die man gesetel. Mans het lewenslank in die plek en die omgewing van hulle geboorte deurgebring. Daar is hulle aan 'n netwerk van familie-bande verbind. Na die man is opgesien en hy was 'n rolmodel vir die jongeres (Van Aarde 2001:120). Binne familieverband was die pa weer die sentrale figuur. Enersyds het hy God in die familie verteenwoordig en andersyds moes hy sorg dat 
God in die familiekonteks aanbid word. God en familie is op ' $\mathrm{n}$ besondere manier verbind. Om God te kon ervaar, moes iemand deel van 'n familie wees: "One had to belong to a family to enjoy God's blessings, and, within the family, the father's status was divinely ordained. And so, the divine and the human met each other at the most intimate level, the familial" (Van Aarde 2001:121). Die familie, die sterk familiebande, die verwantskap met ander families asook die sterk rol van die pa het 'n kind se identiteit en lewensweg bepaal. Dit was 'n sosiale kaart aan die hand waarvan hy homself kon oriënteer, kon legitimeer en sy weg deur die wêreld kon vind (Van Aarde 2001:119). Wie buite die familieband moes bestaan, se lewe was hel.

\section{5. 'N KATEGORIE-VYF-KIND IS VIR ONS GEBORE}

Streng voorsorg is getref dat mense binne die familiegroep trou. So kon hulle verseker dat die "heilige saad" of "die kinders van Abraham" (die fisiese nageslag van Abraham) uitgebrei word (Van Aarde 2001:131). Jesus sou egter buite staan. Wie sy ma presies was, is onbekend. Van Aarde (2001:101-102, 147-148, 151) sê nie reguit dat sy ongetroud was toe sy Jesus verwag het nie. Dit kan ook wees dat haar man (soos dikwels voorgekom het) haar tydens swangerskap verlaat het. So 'n vrou is dan 'n "hoer" genoem en haar kind as die sondige gevolg van 'n owerspelige verhouding beskou (Van Aarde 2001:73). Klaarblyklik was Jesus so 'n kind (Van Aarde 2001:80). Hy sou altyd die smet van die gemeenskap dra. Volgens die amptenare van die tempelstaat in Jerusalem was hy niks anders as 'n kategorie-vyf-kind nie (Van Aarde 2001:132).

Die Joodse religieuse leiers het mense in verskillende groepe verdeel. Van heilig tot minder heilig tot onrein. Boaan was die priesters, dan die Leviete, volbloed Jode, kinders van priesters, ensovoorts. Basies was daar sewe kategorieë van mense en met behulp hiervan is bepaal wie met wie kon trou. Kategorie vyf interesseer ons. Hierdie groep het bestaan uit basters, vaderloses (hulle wie se pa's onbekend is), vondelinge en gekastreerdes. Vaderloses is onder andere hulle wat uit verbode verbintenisse gebore. Kategorie ses het bestaan uit hermafrodiete of mense met misvormde geslagsorgane. Diesulkes kon in elk geval ook nie trou nie. In die laaste, die sewende kategorie was die mense van 'n ander etniese afkoms. Hulle het buite die verbond gestaan en Israel moes ook nie met hulle meng nie (Van Aarde 2001:132). Volgens Van Aarde moet ons Jesus in kategorie vyf soek: "The image of the historical Jesus as the fatherless carpenter ... fits the ideal-type of the fifth category" (Van Aarde 2001:133). 
Jesus kon kwalik in slegter omstandighede gebore gewees het. Van die begin af was hy 'n “nobody" en 'n uitgeworpene (Van Aarde 2001:60-61,110-111). Spatsels van sy buite-egtelikheid verneem ons ook in die literatuur. Ons noem 'n paar. In die Thomasevangelie (105) sê Jesus dat wie sy pa of ma nie ken nie, is die kind van 'n hoer en daarom sondig. In Markus 6:3 word na Jesus as die seun van Maria verwys. Daar is geen verwysing na sy pa nie. Volgens Johannes 19:9 het Pilatus Jesus gevra waar hy vandaan kom. Jesus het geswyg en dit stem met 'n rabbynse voorskrif ooreen: as iemand nie weet wie sy pa of ma is nie, moet hy swyg (Van Aarde 2001:74). Die vroue in Jesus se geslagsregister was van twyfelagtige karakter: Tamar het Juda bedrieg en uit die verbintenis is Peres en Serag gebore (Gen 38:6-30); Ragab was 'n prostituut (Jos 2:1); Rut was 'n vreemdeling en 'n buitestaander (Rut 4:1-17); Solomo se ma was "die vrou van Urija" (Matt 1:6) wat Dawid ter wille van sy eie begeertes laat sterf het. Jesus se voorgeslag het uit oneervolle mense bestaan en hy het geen eer gehad om te verdedig nie: "Matthew's version of Jesus' genealogy places him among the disreputable ... These foremothers of Jesus were dishonorable people ... there was no honor te defend" (Van Aarde 2001:150).

Vaderloosheid het 'n somber toekoms vir Jesus voorspel. Almal sou sy toestand ken en hom soos verminkte behandel. Hy sou ook nooit iets kon doen om die sonde (wat die sisteem hom opgelê het) te ontkom nie. Daar sou nooit 'n pa wees met wie hy hom kon identifiseer of wat hom binne die gesin as kind sou aanvaar nie (Van Aarde 2001:133; vgl 2001:5, 14-15, 46, 77, 78, 118). Hy sou identiteitsloos leef; hy sou nooit werklik een met die Joodse gemeenskap wees nie; hy sou nie deel van die ware Israel of die geslag van Abraham wees nie; hy sou tot by die tempel se hof vir heidene kon ingaan en nie verder nie; hy sou nooit sy hart op 'n rasegte Jodin kon verloor nie; hy sou slegs met 'n onreine kon trou; hy sou leef soos iemand wat buite die verbond staan, soos iemand wat God nie ken nie en wie God ook nie raaksien nie (Van Aarde 2001:74, 119, 126-127;). Kortom: Jesus was inderdaad 'n "nobody."

\section{DIE VOLWASSE JESUS}

Aanvanklik kon Jesus 'n kleinboer gewees het. Waarskynlik was hy nie 'n maklike persoon nie en was iets van sy latere rewolusionêre gedrag dalk vroeg reeds sigbaar. Aanvanklik was hy deel van die Galilese kleinboerderygemeenskap en het weg van sy familie gewoon. Hoë belasting het hom dalk na sy skrynwerkersambag teruggedryf 
(Van Aarde 2001:77). Waarskynlik is daar 'n paar dinge wat ons van Jesus se volwasse-word-jare weet:

- Hy was ongetroud (Van Aarde 2001:77). Waarskynlik het sy herkoms en die streng huwelikswette gedurende die eerste eeu hom verhoed: "Radically opposed to what the conventions of the temple cult of Jerusalem prescribed, he (was), an unmarried outsider (Van Aarde 2001:183).

- Hy het 'n gespanne verhouding met sy familie gehad. Met sy ma het hy nie 'n goeie verhouding gehad nie en met sy broers klaarblyklik nog minder (Van Aarde 2001:77).

- Hy het 'n skerp sondebewussyn gehad. Sy buite-egtelikheid het hom 'n sondaar gemaak. Hiermee word "sistemiese sonde" bedoel. Hy het swaar aan die smet, wat die samelewing hom as buite-egtelike opgelê het, gedra (Van Aarde 2001:4$5,132-134,182-183)$.

- Hy het oor 'n pa gefantaseer. As vaderlose en familielose het hy daaroor gefantaseer om 'n pa te hê eerder as om self pa te word. 'n Vaderlose seun wat alles van sy ma ontvang het, identifiseer nie eintlik met haar nie (Van Aarde 2001:65). Van haar het hy reeds alles ontvang en hy bly daarom na 'n pa hunker (Van Aarde 2001:121).

- Hy het 'n kinderlike vertroue op God gehad. As vaderlose wend hy hom tot God; beleef hy God as vader tot wie hy onbelemmerde toegang kon hê. Kortom: in Jesus se stryd met die gevolge van sy vaderloosheid het God sy vader geword (Van Aarde 2001:134,153-154).

- Hy het na 'n gesin en familiebande verlang. Omdat hy buite die normale gesinsverband gestaan en die bitterkant van vaderloosheid ervaar het, het die begeerte na 'n familie ontstaan. 'n Familie waar hy kon tuisvoel en kon hy behoort (Van Aarde 2001:149).

\section{JESUS EN JOHANNES DIE DOPER}

Op 'n gegewe moment was daar 'n populêre volksbeweging onder leiding van 'n ene Johannes. Waarskynlik is dit ook deur ontevredenheid met die Romeinse heerskappy aangevuur, maar die vernederende tempelideologie was die eintlike vonk. Hiervolgens het Jerusalem bepaal wie se sondes vergewe sou word en hoe dit moes gebeur. Volgens hulle mensgradering het die priesters selfs besluit wie toegang tot 
God mag hê en wie nie (Van Aarde 2001:68). Hierteen het Johannes hom verset. 'n Kenmerk van Johannes se doop was 'n apokaliptiese verwagting: hy het die spoedige oordeel van God verwag en daarom moes mense hulle sondes bely en gereinig word (Van Aarde 2001:113).

Op 'n dag het Jesus hom ook laat doop. Dat Johannes Jesus gedoop het, is volgens Van Aarde histories waar (Van Aarde 2001:66; vgl 55-63). Hierdie gebeurtenis is egter later vanuit 'n bepaalde teologiese perspektief geïnterpreteer en op 'n bepaalde manier hervertel of herskryf (Van Aarde 2001:60). Waarom het Jesus hom laat doop? Waar-skynlik was hy ook soos Johannes van sonde, berou, vergifnis en bekering oortuig (Van Aarde 2001:66). Wat was egter die aard van Jesus se sondebewussyn? Hy het swaar onder "sinful sickness" gebuk gegaan. Van sy neerdrukkende stigma as 'n vaderlose wou hy ontslae raak. Hy is deur die samelewing tot sonde gemaak en daarom die behoefte aan sondevergifnis (Van Aarde 2001:53). Na sy doop het Jesus na Galilea teruggekeer. Daar het hy nie Johannes se doopspraktyk voortgesit nie, maar met 'n eie bediening begin (Van Aarde 2001:182183). Dit het die volgende kenmerke vertoon:

- Hy het met sondaars gemeng. Hulle wat volgens die gangbare tempelteologie nie deel van Abraham se geslag was nie, het hy deel van God se familie gemaak (Van Aarde 2001:69).

- Hy het mense innerlik genees. Diegene wat van hulle sonde bewus was, kon vergifnis smaak (Van Aarde 2001:67-70; vgl Craffert 1999a:88-129).

- Hy het van God se direkte onbemiddelde teenwoordigheid geleer. Volgens die tempelpriesters moes die buitestaanders geleef het asof daar nie 'n God was nie. Volgens Jesus kon hulle sonder tussenfigure (bv tempelamptenare) en ongeag hulle toestand (as uitgeworpenes deur die samelewing) God se teenwoordigheid ervaar (Van Aarde 2001:68, 77, 113, 114).

- Hy het 'n bepaalde ervaring met God gehad. Van Aarde verwys daarna as 'n "altered state of consciousness" (Van Aarde 2001:12,76) en "his foundational experience of God" (Van Aarde 2001:196, 197). Wat dit presies was, is onseker, maar miskien het dit Jesus se religieuse oortuiging versterk dat God sy vader was, dat hy God se kind was en God se koninkryk inklusief was.

- Hy het van die koninkryk van God vertel. Johannes het gemeen dit moet nog kom en dat dit op 'n apokaliptiese wyse sal aanbreek. Volgens Jesus het dit reeds 
aange-breek. Aan hierdie koninkryk behoort die geestelike nageslag van Abraham en die lede van die koninkryk word die "familie van God genoem" (Van Aarde 2001:53, 54, 66, 67, 68, 149).

\section{DIE AARD VAN JESUS SE BEDIENING}

Jesus se bediening was rewolusionêr. Dit was op die uitgeworpenes, die buitestaanders, die onreines gerig. In sy kinderbediening kom dit die beste navore. Hy het ' $n$ besondere hart vir die verstotelinge binne die Joodse gemeenskap gehad: die vaderlose kinders wat identiteitsloos in strate en krotbuurtes groot geword het. Jesus, die vaderlose, het dus 'n oog vir ander vaderloses en hulle onmenslike lot gehad (Van Aarde 2001:135-154). Sy werk verkry besondere betekenis wanneer ons dit in die lig van die antieke gebruik van kinderverwerping verstaan. Alhoewel Jode en die latere Christene nie hieraan deelge-neem het nie, was dit 'n bekende gebruik om pasgebore kinders êrens buite neer te sit om te sterf. Dit was veral die lot van ongewenste kinders: hulle wat gestremd was, uit onwettige verbintenisse gebore is, misvormd en geestesversteurd was, nie arm of oog gehad het nie, die blindes, melaatses, dowes, stommes. Om hierdie verskriklike dade te regverdig, is dikwels aangevoer dat die kinders demone was of met die een of ander vyandige gees vervul is (Van Aarde 2001:139-140).

Jesus het dus op die swakste element in die samelewing gefokus. Hulle lot wou hy verander deur hulle deel van 'n familie of dan God se familie te maak. Volgens Van Aarde word dit uitstekend in die Evangelium Infantium in Markus 10:13-16 geïllustreer.

Die mense het kindertjies na Jesus toe gebring dat Hy hulle moet aanraak. Sy dissipels het met die mense daaroor geraas. Maar toe Jesus dit sien, was Hy verontwaardig en het Hy vir hulle gesê: "Laat die kindertjies na My toe kom en moet hulle nie verhinder nie, want die koninkryk van God is juis vir mense soos hulle. Dit verseker Ek julle: Wie die koninkryk van God nie soos 'n kindjie ontvang nie, sal daar nooit ingaan nie". Hy het sy arms om die kindertjies gesit, hulle die hande opgelê en hulle geseën.

(Mk 10:13-16, my kursivering) 
Hierdie gedeelte (veral die kursiewe frases) moet ons in noue verband met Jesus se genesingswonders verstaan. Woorde en uitdrukkings word gebruik wat eie aan hierdie genesingsbeskrywings is: mense is na Jesus gebring (in die sinoptiese evangelies is dit 'n tipiese uitdrukking om te vertel hoe mense na Jesus gebring is sodat hy hulle kon genees het); hy moes hulle aanraak (in die sinoptiese evangelies word dit slegs in verband met wonderverhale en mededelings oor die dooies wat opstaan, gebruik); die dissipels het met hulle geraas (hierdie uitdrukking word in die Nuwe Testament in verband met die wonderverhale aangewend); hulle wou die kinders verhinder (laasgenoemde staan in verband met 'n "miraculous exorcism" in Matt 19:14 en Mark 9:38-41); dat Jesus sy arms om hulle geplaas het, dui op besondere toegeneentheid (Diodurus Siculus gebruik hierdie uitdrukking gedurende die eerste eeu $\mathrm{vC}$ in 'n konteks waarin kinders genees is); Jesus het sy hande op die kinders gelê en hulle geseën (dit dui op 'n tipiese rite in die genesingspraktyk) (Van Aarde 2001:135-140).

Waarin lê dan die rewolusionêre, die anderse van Jesus se bediening? In die feit dat hy die destydse samelewingsideologie en die -waardes trompop geloop het. Hy het hom teenoor die patriargale familiesisteem gestel en vir die "outcasts" gekies. Vir die onreines, die onvolmaaktes, die Godvervreemdes, "die volk wat in duisternis woon" (Matt 4:16). Verder het hy 'n kind en nie 'n man of 'n familiehoof nie, as model vir toelating tot die koninkryk van God geneem. Om die koninkryk van God te beërwe, moet 'n mens soos ' $n$ kind word. Nie soos 'n man of 'n vaderfiguur nie, maar soos 'n kind. In bogenoemde Markusgedeelte word kinders genees van die sosiale smet wat hulle vanweë die samelewing aankleef; word hulle in die koninkryk van God opgeneem; dien hulle as voorbeelde: "Wie die koninkryk van God nie soos 'n kindjie ontvang nie, sal daar nooit ingaan nie" (Mark 10:15). Omdat Jesus vir die uitgeworpenes gekies het, het Jesus nuwe sin en betekenis gegee aan die misrabele lewens van onderdruktes "among whom were women and children living at the fringe of society because they were the nobodies (the divorced and the fatherless, the widows and the orphans) to whom patriarchy gave no place amidst the honorable" (Van Aarde 2001:148).

\section{HY HET GESTERF EN OPGESTAAN}

Jesus het die tempelideologie van sy tyd uitgedaag en die samelewing trompop geloop. Hy het sy dorpsgenote kwaad gemaak en hom die toorn van die Fariseërs, Herodiane, priesters en ouderlinge in Jerusalem op die hals gehaal. Waarskynlik het 
sy konfrontasie met die owerhede sy lewe gekos: "The kind of life Jesus lived led to his death" (Van Aarde 2001:189). Op 'n dag het dinge te ver gegaan en na 'n woedeuitbarsting by die tempel het die Romeine Jesus gegryp en hom gekruisig (vgl Van Aarde 2001:168-169). Hy is onder onbekende omstandighede dood en sy liggaam is nie in 'n familiegraf neergelê nie (Van Aarde 2001:78; Craffert 1999c:85-101). Jesus het as 'n "nobody" gesterf en is waarskynlik saam met ander "nobodies" begrawe. Sy navolgers het sy dood egter as "a filial act of obedient submissiveness to God, his heavenly Father" gesien (Van Aarde 2001:134).

Alles sou verby gewees het as Jesus se navolgers nie oor hom begin praat het nie. In hulle vertellinge het hy opgestaan: "Jesus arose in the kerygma". Anders gestel: "Jesus lived on through the retelling of his cause" (Van Aarde 2001:185). As gevolg hiervan het Jesusbewegings ontstaan waarin mense oor hulle "opstandingservaringe" vertel het. Vir hulle was dit asof hulle die opgestane Jesus "in an altered state of consciousness" ervaar het (Van Aarde 2001:185). Mettergaan het die kerk ontstaan. So iets was egter nie eers in Jesus se verste gedagtes nie (Van Aarde 2001:184). Sy navolgers het sy werk en dood so begin interpreteer dat die kerk sy basiese gedagtes voortgesit het: die kerk was 'n versameling van "nobodies" wat God "Vader" genoem het en mekaar se gelykes was (Van Aarde 2001:188; vgl 202204).

\section{HY IS IN WOORDE VASGEVAT}

Jesus se navolgers het ook oor hom begin skryf. Hoe moes hulle dit doen? Tussen gebeure en die neerskryf daarvan het 'n lang tyd verloop. In Van Aarde se boek kry 'n mens iets van die vroeë kerk se worsteling om die onvatbare te vat en die onverwoordbare te verwoord (Van Aarde 2001:155-183). Al die uiteindelike skryfsels oor die historiese Jesus (soos die Nuwe Testament) deel egter een enorme beperking: dit het die historiese Jesus verloor. Ons sou dit soos volg kon verduidelik:

- Toe daar vir die eerste keer oor Jesus geskryf is, was die Jesusgebeure reeds weg. Direkte toegang tot die Jesusverlede was nie meer moontlik nie. Toe oor hierdie geskiedenis nagedink en geskryf is, was dit alreeds te laat: die vergange Jesuswerklikheid het reeds verdwyn. Die Jesusgebeure ontsnap daarom tot vandag toe enige greep van die historiese rede. Daarom kan hierdie gebeure nooit vanuit die Nuwe Testament vasgevat, mooi bekyk en volledig beskryf word nie. Wanneer 
die Jesusverlede (asook enige historiese gebeure) bestudeer word, staan die historikus/ Nuwe Testamentikus altyd weer verleë want sy of haar greep skiet ver te kort (Goosen 1998:55).

- Al wat van die Jesusverlede oorgebly het, is "die spore, die merke of tekens wat die gebeure in haar vlugtog voor die denke uit agterlaat het" (Goosen 1998:56). Anders gesê: al wat die historikus/Nuwe Testamentikus het, is die spore van die Jesus-gebeure in die Nuwe Testament. Nie die vergange werklikheid in al sy volheid nie, maar die merke en tekens van die historiese Jesus. Wat ons dus van die Jesusverlede weet, is nie die eintlike gebeure nie. Dit sal ons altyd ontsnap (vgl Derrida 1997:102-107).

- 'n Gevoel van verlies en rou moet eie aan die historikus/Nuwe Testamentikus wees. Toe die Jesusverlede verwoord is, is die besondere (die historiese Jesus) onmiddellik verloor; toe die Jesusverlede talig gemaak is, is dit veralgemeen en is die partikuliere van die gebeurtenis (die Jesusgebeure) onmiddellik verloor (Derrida 1995:377). En dit is 'n enorme verlies. 'n Verlies wat nooit weer omgekeer kan word nie en daarom die oorheersende gevoel van rou. Omdat die verlies absoluut is, is die rou ook absoluut. Niks kan daaraan gedoen word nie. Die historikus/Nuwe Testamenti-kus kan net "huil oor die onvervangbare verlies en sy eie onmag ten opsigte daarvan, oor die (vuur-)as wat die singuliere as getuie van haar vlugtige aanwesigheid agtergelaat het" (Goosen 1998:70). Of soos Derrida dit gestel het: "Deep down, deep down inside, the eye would be destined not to see but to weep" (Caputo 1997:326; Le Roux 1998:477-486).

- Alle pogings om Jesus te beskryf, was dus geheel en al histories bepaald. Paulus, Johannes, en andere het geneem wat voorhande was en Jesus aan die hand daarvan beskryf. Niks in die Nuwe Testament is daarom bowe-aards nie; geen uitdrukkings-vorm (taal, beeld, konsep) was vreemd aan die tyd nie. Die beskrywing van Jesus in die Nuwe Testament was volledig eietyds: dit reflekteer die (beperkende) denkwyse van die eerste-eeuse Mediterreense wêreld. Gevolglik is Jesus met behulp van botsende voorstellingswyses voorgestel (vgl hieronder).

\section{WAS HY WONDERWERKER?}

Toe die Jesuservaring deur die Nuwe-Testamentskrywers verwoord is, moes hulle 'n paar goed bymekaargebring. Hy was 'n mens, maar tog was daar ook iets 
bowemenslik aan hom; hy was vaderloos, maar het God as Vader gehad; hy was 'n identiteitslose en uitgeworpe kind, maar word mettergaan God se kind. Hoe moes die skrywers hierdie tweekantigheid van Jesus verwoord?

Daar was die "poging” van die sinoptiese evangelies. Hierdie skrywers het by die Griekse denke aangesluit. Hiervolgens was dit makliker om die goddelike en die mens-like te verenig. Iemand wat van goddelike oorsprong was, kon in die vorm van 'n mens verskyn en selfs aan die lotgevalle van menswees deelkry. 'n Kind wat uit 'n god sowel as ' $n$ mens gebore is, het die goddelike en menslike in hom verenig. So 'n kind is dan "seun van god" genoem en hy kon groot heldedade verrig. So 'n vereniging tussen die goddelike en die menslike was vir die Griek geen probleem nie. Die goddelike het nie die ware menslike aard van so 'n godeseun vernietig nie en ook andersom. Vir hulle was dit 'n misterie en 'n paradoks waarmee saamgeleef moes word. Alle aandag is eerder op die lewe van so 'n godmens gefokus: die wonderwerke en heldedade wat hy verrig het. Soms is hierdie godeseuns ook as redderfigure beskou en selfs in die kultus aanbid. Sommige het ook gesterf, maar weer opgestaan. Aanbidders kon deur middel van bepaalde rites aan die godeseun se dood en opstanding deelkry (Van Aarde 2001:155-157).

In die sinoptiese evangelies word Jesus as 't ware met 'n Griekse bril gelees en verstaan. Met behulp van hierdie Griekse tradisie kon die skrywers van die sinoptiese evangelies die geboorte van Jesus as wonderbaarlik beskryf. Maagdelike geboortes was 'n doodnormale gebeurtenis. Christene uit die heidenwêreld was bewus van verhale oor sulke geboortes wat in Egipte, Griekeland, Anatolië en ander streke vertel is. Sketse en tekeninge wat na bonatuurlike geboortes verwys, is in huise in Herculaneum en Pompei gevind. Sulke afbeeldinge "provide a clear indication that miraculous birth stories were common and well known" (Van Aarde 2001:104). In sommige Griekse mites was die moeder van 'n godeseun wel 'n maagd. Perseus is gebore uit die verbintenis tussen die maagd, Danae, en die god, Zeus. Laasgenoemde het Danae in die vorm van 'n goue straal deur 'n klein venstertjie bevrug (Van Aarde 2001:162). Van Aarde se boek het 'n belangrike bydrae tot ons verstaan van die alledaagsheid van sodanige geboortes gemaak: "Contemporary sketches and portrayals of divine birth and/or virginal conception and adoption ... were well known when the New Testament was written" (Van Aarde 2001:165).

Iemand wat wonderbaarlik gebore is, kon wonderwerke verrig. In die Griekse wêreld was bonatuurlike kragte die resultaat van so 'n wondergeboorte. Asclepius was ' $n$ voorbeeld hiervan. Hy is deur Apollo uit sy moeder se buik geruk sodat hy 'n 
bonatuurlike waarsêer en 'n gesondmaker kon wees (Van Aarde 2001:160). Jesus was 'n ander voorbeeld. Hy het sy goddelike gesag deur sy wonderdade bevestig. Vir die Christene uit die Joodse wêreld was dit 'n aanvaarbare manier om so oor Jesus te praat. Mense soos Moses, Dawid en die profete was ook heilige manne wat die gees van Jahwe ervaar het en groot dinge gedoen het. Jesus was 'n soortgelyke figuur: hy was boweaards en het wonders verrig. Kortom: "In the first type of the combination of the divine and human, the divine figure was a miracle worker filled with the Divine Spirit" (Van Aarde 2001:158). Kortom: dat Jesus, die Seun van God, volgens Matteus (1:18-25) en Lukas (1:26-38) maagdelik gebore is, was dus geensins vir die mens van eerste eeu abnormaal nie. Dit het gepas by Jesus die wonderwerker en geneser (Van Aarde 2001:165).

\subsection{Jesus was anders}

Paulus en Johannes het anders hieroor gedink. Jesus was 'n pre-eksistente wese wat mens geword het. Waarskynlik was Filippense 2:6-11 'n pre-Pauliniese himne wat Paulus se denke uitstekend verwoord het: "Hy wat in die gestalte van God was ... het Homself verneder deur die gestalte van 'n slaaf aan te neem en aan mense gelyk te word”. Binne hierdie konteks was daar nie plek vir maagdelike geboortes en wonders nie. By Paulus verrig Jesus dan ook geen wonderwerke nie. Hierdie selfvernedering van die pre-eksistente Christus het selfs vir die gelowige se daaglikse lewe konsekwensies gehad: "Dieselfde gesindheid moet in julle wees wat daar ook in Christus Jesus was" (Fil 2:5).

Van Aarde beklemtoon die verskil tussen hierdie twee denkwyses: "In a certain sense, these two types were mutally exclusive" (Van Aarde 2001:158). In die sinoptiese evangelies se wonderverhale word Jesus triomfantelik voorgestel: die Seun van God wat bonatuurlik gebore is, verrig wonderdade. Vir Paulus is Jesus se dade nie deur krag nie, maar deur swakheid en broosheid gekenmerk, selfs aan die kruis. Johannes beklemtoon weer die paradoks dat 'n pre-eksistente wese, wat aan God gelyk was, volledig mens kon word (Van Aarde 2001:161).

Uit hierdie twee voorbeelde blyk die onmoontlikheid om agter die tekste by die outentieke Jesus uit te kom. Klaarblyklik het die Nuwe-Testamentskrywers self nie geweet hoe om hom in woorde vas te vat nie. En toe die historiese Jesus talig gemaak is, het die skrywers hom verloor. Toe hulle die Jesusverlede neergepen het, het hulle die gebeure verloor. 


\subsection{Wie was sy pa nou eintlik?}

Hierop moet ons nog antwoord. Voordat ons egter hierdie vraag beantwoord, moet twee sake baie goed verstaan word. Een is dat Jesus vaderloos was. Van Aarde stel dit oor en oor: "no biological father played a role in his life" (Van Aarde 2001:108); "no one knew ... that Joseph was his father (Van Aarde 2001:109); "there is no trace of a father in Jesus' life in historical Jesus material" (Van Aarde 2001:118). Daar is nog iets: Jesus het God "vader" genoem. Jesus se hunkering na 'n vader is deur God self gevul: "For Jesus, God filled this emptiness" (Van Aarde 2001:118). Eintlik pas 'n biologiese pa nie mooi in Van Aarde se Jesusverhaal nie. So iemand is eintlik nie nodig nie. En tog word Jesus die "seun van Josef" genoem.

Volgens Van Aarde is die Josef-Jesus-skakel 'n legende wat eers na Jesus se dood ontstaan het. Waarskynlik was dit bedoel om skinderstories oor Jesus se buiteegtelik-heid te besweer. In sinagoges en die Jamnia Akademie is sy vaderloosheid met ontug gelykgestel. Om die Jesusboodskap te red, is die Joseflegende toe ontwerp (Van Aarde 2001:113). Waarom Josef? In 'n sekere sin was dit voor die hand liggend. Josef in die Ou Testament verteenwoordig as 't ware die streek waar Jesus vandaan kom: dit was die gebied waar die noordelike stamme hulle gevestig het en die Josefstamme 'n baie prominente rol vervul het (Van Aarde 2001:82-108). Volgens Lukas kon die wêreld in konsentriese sirkels beskryf word: eers Judea, dan Samaria en ten slotte Rome wat die groter wêreld verteenwoordig het. Josef is baie nou aan Samaria gekoppel. Mettergaan het hy vir die Fariseërs die teenvoeter van Juda geword; 'n bastervolk tussen die Jahwevolk en die heidene; 'n groep van uitgeworpenes (Van Aarde 2001:98). Vanweë die Josefskakel is Jesus van Galilea aan die Samaritane en die uitgeworpenes gekoppel. In Lukas se gelykenis van die Barmhartige Samaritaan (Luk 10:30-35) vervul Jesus die rol van sowel die Samaritaan as die Israeliet (Van Aarde 2001:111).

Hierdie Jesus-Josef-skakel bind Jesus ook aan die Josef van Genesis 37-50. Met behulp hiervan kon die vroeë kerk 'n ander faset van die historiese Jesus se lewe verduidelik. Josef was ook die slagoffer van skinderpraatjies. Hy is deur sy broers verwerp, vir veertig stukke goud verkoop, maar tog uiteindelik tot onder-farao verhoog. So was dit ook met Jesus, die seun van Josef, gesteld. Hy was ook gehaat en verneder. Hy is as 'n sondaar, 'n Samaritaan en 'n buite-egtelike uitgeskel. En tog het hy getriomfeer. Josef het 'n toonbeeld van vergifnis en medelye geword (Gen 50:17) en Jesus het ten spyte van al die haat teen hom die kosmos lief gehad (Van Aarde 2001:94-95). 


\section{2. 'N SLOTWOORD}

Van Aarde se boek oor die historiese Jesus is 'n hoogtepunt in die Suid-Afrikaanse Bybelwetenskap. Dit dwing ons om histories te dink, na die vroegste bronne oor Jesus deur te dring, Jesus as 'n eerste-eeuse Mediterreense mens te waardeer, en sy totale menswees raak te sien. Van Aarde help ons om die worsteling met die opskrifstelling van die Jesusgebeure te verstaan. Elke poging was histories bepaald en selfs uitsluitend. 'n Vaste greep op die historiese Jesus was en is nog steeds byna onmoontlik. En tog blyk dit uit Van Aarde se werk dat ons genoeg weet om die buitelyne van die historiese Jesus te trek. Genoeg is bekend dat ons iets van die historiese Jesus se radikale omgee vir die ander kan verstaan. Uiteindelik is Van Aarde se skets van Jesus anders, selfs skokkend anders, maar daarin lê juis sy skoonheid en aantrekkingskrag.

Van Aarde is 'n man van die kerk en daarom die hoop dat sy historiese Jesus ook vir die geloofsgemeenskap iets sal beteken. Hy is bewus van die moontlikheid dat sekularisasie asook postmodernisme die Jesuskerugma (die geloofsinterpretasies van die kerk oor die al eeue) kan ondermyn; dat die kerk as instelling kan verdwyn en die Christelike Bybel se kanoniese gesag verlore kan gaan. Teen hierdie agtergrond behoort ' $n$ mens opnuut na die betekenis van die historiese Jesus te vra; behoort gelowiges die moed van oortuiging aan die dag lê om na die historiese Jesus (gestroop van alle latere interpretasie) te soek (Van Aarde 2001:204).

So 'n soeke na die historiese Jesus het groot betekenis vir die soeker. Elkeen sal ontdek wie hierdie Jesus vir hom of haar in sy of haar daaglikse lewensgang is. In die geval van Van Aarde is dit op 'n treffende wyse waar. Sy boek is aan sy pa opgedra. Met hom het Van Aarde egter nie 'n goeie verhouding gehad nie. Van Aarde het die pyn van vaderloosheid geken en daarom het die vaderlose Jesus hom aangespreek. Hy het geleer wie Jesus was en wat hy nou nog vir mense kan beteken (Van Aarde 2001:6; vgl Schweitzer 1936:401).

Schweitzer was reg. Wie hom met die historiese Jesus besighou, sê uiteindelik meer van homself en haarself as van die historiese Jesus. En hierin is die aantreklikheid en uitdaging van Van Aarde se boek oor die historiese Jesus geleë (Schweitzer 1936:4-6; vgl Bultmann 1951:7).

\section{Literatuurverwysings}


Borg, J 1987. Jesus: A new vision. San Francisco: Harper Collins.

Botha, P J J 2000. Everyday life in the world of Jesus. Pretoria: Biblia Publishers.

Bultmann, R 1951. Jesus. Tübingen: J C B Mohr (Paul Siebeck).

Caputo, J D 1997. The prayers and tears of Jacques Derrida. Indianapolis: Indiana University Press.

Craffert, P F 1999a. Illness and healing in the Biblical world: Perspectives on health care. Pretoria: Biblia Publishers.

Craffert, P F 1999b. Mediating divine powers: Perspectives on religion in the biblical world. Pretoria: Biblia Publishers.

Craffert, P F 1999c. Meeting the living among the dead: Burials, tombs and the afterlife. Pretoria: Biblia Publishers.

Den Heyer, C J 1996. Opnieuw: Wie is Jezus?. Zoetermeer: Meinema.

Derrida, J 1995. Points ... Stanford: University Press.

Derrida, J 1997. Limited Inc. Evanston, Illinois: Northwestern University Press.

Du Toit, A B (red) 1985. Handleiding by die Nuwe Testament. Pretoria: N G Kerkboek-handel.

Du Toit, A B 1985. Die historiese Jesus en die verkondigde Christus van die Evangelies, in Du Toit (red), 257-279.

Goosen, D 1998. Verlies, rou en affirmasie: Dekonstruksie en die gebeure. Fragmente 1, 54-79.

Gunkel, H 1926/1927. The "Historical Movement" in the study of religion. ExpTimes 38, 532-536.

Klapwijk, J 1970. Tussen historisme en relativisme. Assen: Van Gorcum \& Comp.

Le Roux, J H 1993. The story of two ways: Thirty years of Old Testament scholarship in South Africa. Pretoria: Verba Vitae.

Le Roux, J H 1996. Andries van Aarde se Matteusinterpretasie. HTS 52(4), 653-670.

Le Roux, J H 1997. Our historical heritage. Old Testament Essays 10(3), 401-423.

Le Roux, J H 1998. Israel's history and a sense of loss. Old Testament Essays 11(3), 477-486.

Pelican, J 1971. The emergence of the Catholic tradition (100-600). Chicago: University of Chicago Press.

Schnelle, U 1999. Einleitung in das Neue Testament. Göttingen: Vandenhoeck \& Ru-precht.

Schweitzer, A 1936. The quest of the historical Jesus. London: A \& C Black. 
Troeltsch, E 1913. Historiography, in Hastings, J (ed), Religion and ethics, 716-723. Edinburgh: T \& T Clarke.

Troeltsch, E 1922. Ueber historisch und dogmatische Methode in der Theologie. Gesammelte Schriften II, 729-753. Tübingen: J C B Mohr.

Van Aarde, A G 1999. The historicity of the circle of the Twelve: All roads lead to Jerusalem. HTS 55(4), 795-826.

Van Aarde, A 2001. Fatherless in Galilee: Jesus as child of God. Harrisburg: Trinity Press International.

Von Harnack, A 1908. Das Wesen des Christentums. Leipzig: Heinrichsche Buchhand-lung.

Von Harnack, A 1990. Marcion: The Gospel of the alien God. Durham: Labyrinth Press.

Thiselton, A C 1980. The two horizons. Exeter: Pater Noster.

Weber, M 1949. The methodology of the social sciences. New York: The Free Press. 